\title{
EAT BREATHE EXCRETE REPEAT: Physiological Responses of the Mussel Mytilus galloprovincialis to Diclofenac and Ocean Acidification
}

\author{
Marco Munari ${ }^{1, *,+}{ }^{\oplus}$, Valerio Matozzo ${ }^{1} \mathbb{D}$, Verena Riedl ${ }^{1}$, Paolo Pastore ${ }^{2} \mathbb{C}$, Denis Badocco ${ }^{2}$ \\ and Maria Gabriella Marin ${ }^{1}[$ \\ 1 Department of Biology, University of Padova, via Ugo Bassi 58/B, 35121 Padova, Italy; \\ matozzo@bio.unipd.it (V.M.); vriedl@web.de (V.R.); mgmar@bio.unipd.it (M.G.M.) \\ 2 Department of Chemical Sciences, University of Padova, Via Marzolo 1, 35131 Padova, Italy; \\ paolo.pastore@unipd.it (P.P.); denis.badocco@unipd.it (D.B.) \\ * Correspondence: marco.munari@szn.it; Tel.: +39-081-5833512 \\ + Current Address: Department of Integrative Marine Ecology, Ischia Marine Centre, Stazione Zoologica \\ Anton Dohrn, Punta San Pietro, 80077 Ischia (Naples), Italy.
}

Received: 27 September 2020; Accepted: 10 November 2020; Published: 12 November 2020

\begin{abstract}
Combined effects of the nonsteroidal anti-inflammatory drug diclofenac and lowered seawater $\mathrm{pH}$ were assessed on the physiological responses of the mussel Mytilus galloprovincialis. Bivalves were exposed for 1 week to natural $\mathrm{pH}(8.1)$ and two reduced $\mathrm{pH}$ values $(\mathrm{pH}-0.4$ units and $\mathrm{pH}-0.7$ units), as predicted under a climate change scenario. After the first week, exposure continued for additional 2 weeks, both in the absence and in the presence of environmentally relevant concentrations of diclofenac $(0.05$ and $0.5 \mu \mathrm{g} / \mathrm{L})$. Clearance rate, respiration rate, and excretion rate were measured after 7 days of exposure to $\mathrm{pH}$ only and after 14 (T1) and 21 (T2) days of exposure to the various $\mathrm{pH}^{*}$ diclofenac combinations. At all sampling times, $\mathrm{pH}$ significantly affected all the biological parameters considered, whereas diclofenac generally exhibited a significant influence only at T2. Overall, results demonstrated that the physiological performance of $M$. galloprovincialis was strongly influenced by the experimental conditions tested, in particular by the interaction between the two stressors after 21 days of exposure. Further studies are needed to assess the combined effects of climate changes and emerging contaminants on bivalve physiology during different life stages, especially reproduction.
\end{abstract}

Keywords: ocean acidification; diclofenac; bivalves; clearance rate; respiration rate; excretion rate

\section{Introduction}

Marine coastal ecosystems are characterized by high fluctuations of several environmental physical and chemical variables, which the ongoing global climate change (GCC), such as warming and ocean acidification (OA), may exacerbate. The combination of altered abiotic factors with environmental pollutants can pose major threats to marine biodiversity [1-5]. Along coastal areas, in particular, nearby harbors, marinas, and wastewater treatment plans, aquatic organisms may be exposed to a wide range of anthropogenic compounds, such as emerging contaminants that, because of their almost unknown environmental impacts, raise increasing concern [6-10].

Among emerging contaminants, pharmaceutical and personal care products (PPCPs) can be detected in various aquatic systems, such as seawater, surface waters, groundwaters, and effluents from wastewater treatment plants [11-17]. PPCPs are made to target specific metabolic and molecular pathways in humans and farmed animals, but they can exert detrimental effects on nontarget species when released into the environment. 
Being used in both human and veterinary medicine, diclofenac (DFC), a nonsteroidal anti-inflammatory pharmaceutical (NSAID), is frequently detected in sewage and surface waters [18,19], and its concentrations in the marine environment range from a few nanogram per liter to several microgram per liter.

DFC inhibits the cyclooxygenase enzymes (COX-1 and COX-2), which function as a catalyst in the conversion of arachidonic acid to prostaglandins [20] in mammals, while in other taxa, DFC can trigger negative effects, such as gill damage and renal lesion in rainbow trout [21] and kidney damage in vultures [22]. DFC has been shown to induce oxidative stress, DNA damage, alteration in estrogenic activity and affects hemocytes functionality in marine mussels [23-27]. Despite this evidence, there is still a lack of knowledge on the possible negative effects of DFC on marine bivalves' physiological parameters, such as clearance, respiration, and excretion rates. In addition, bivalve physiological parameters might be strongly influenced by the alteration of abiotic factors such as $\mathrm{pH}$ and temperature, alterations that will be exacerbated by the ongoing climate change. In this regard, Liu and He [28] found that the exposure to predicted reduced levels of $\mathrm{pH}$ (7.7 and 7.4) significantly influenced the physiological responses of the scallop Chlamys nobilis and the mussel Perna viridis resulting in strongly reduced excretion and clearance rates. Alterations in physiological rates, such as clearance, respiration, and excretion, may help to understand detrimental effects on growth, survival, and other energy-dependent processes that were observed in several studies on mollusks. In juvenile mussels (Mytilus chilensis), 70-days exposure to high $\mathrm{pCO}_{2}$ levels (750-1200 ppm) led to a significant decrease in energy available for growth (scope for growth) [29]. Matoo et al. [30] showed that long-term exposure to warming $\left(+5^{\circ} \mathrm{C}\right)$ and hypercapnia $\left(\sim 800 \mathrm{ppm} \mathrm{CO}_{2}\right)$ minimally affected the cellular redox status in the hard-shell clams Mercenaria mercenaria and eastern oysters Crassostrea virginica. However, the combined exposure to those stressors resulted in an elevated standard metabolic rate of clams revealing increased expenditure for basal maintenance.

The potential interaction between environmental emerging contaminants and OA is an issue that needs to be addressed. In marine organisms, the interactions between PPCPs and reduced $\mathrm{pH}$ have been studied experimentally mostly at biochemical and cellular levels [26,27,31,32]. At present, there is a gap of knowledge on how changes in environmental variables (temperature, salinity, dissolved oxygen, and $\mathrm{pH}$ ) may influence animals' physiological performance. Consequently, in this study, we evaluated the effects of DFC under OA conditions on physiological responses (clearance rate, respiration rate, and excretion rate) of the mussel Mytilus galloprovincialis.

\section{Materials and Methods}

Specimens of M. galloprovincialis ( $4.0 \pm 0.5 \mathrm{~cm}$ shell length) were collected along the west coast of the Northern Adriatic Sea (near Cavallino Treporti, Italy; temperature of approximately $25^{\circ} \mathrm{C}$ and $\mathrm{pH}$ of 8.2) in July, and transferred immediately to the laboratory. Only bivalves with no shell damage were chosen for the experiments, and epibionts (such as algae and barnacles) were gently removed from the mussels. In the laboratory, individuals were maintained for 7 days in aerated seawater at salinity, temperature, and $\mathrm{pH}$ values similar to those measured during bivalve collection.

\subsection{Experimental Setup for Bivalve Exposure}

Before the experiments, bivalves were acclimatized to the experimental conditions by gradually decreasing the seawater temperature $\left(1^{\circ} \mathrm{C}\right.$ per day) to $22^{\circ} \mathrm{C}$, and by gradually reducing natural $\mathrm{pH}$ values of about -0.4 or -0.7 units (a reduction approximately of 0.1 units per day). The bivalves were fed daily with microalgae (Isochrysis galbana). The experiments were performed during the resting phase, when animals were not sexually active (June/July), to reduce any additional stress that might arise from spawning events during the experiments. The experimental flow-through system (Figure 1) used for mussel exposure was planned at the Hydrobiological Station "Umberto D'Ancona" in Chioggia. It consisted of a main outside reservoir filled with natural seawater (about $1000 \mathrm{~L}$ of capacity). The seawater (mean salinity and $\mathrm{pH}$ values throughout the experiments were $34 \pm 0.4$ and $8.07 \pm 0.04$, respectively) was then pumped into two tanks (about $300 \mathrm{~L}$ each) inside the laboratory 
and equilibrated to the controlled laboratory temperature $\left(22^{\circ} \mathrm{C}\right)$. The seawater next moved on to three tanks of approximately $120 \mathrm{~L}$ capacity, where the $\mathrm{pH}$ was adjusted to experimental values by bubbling $\mathrm{CO}_{2}$ using an automatic control system (ACQ110 Aquarium Controller Evolution by Aquatronica) connected with $\mathrm{pH}$ electrodes (ACQ310N-PH by Aquatronica). In the end, the seawater was pumped $(25 \mathrm{~mL} / \mathrm{min}$, using ACQ450 Dosing pumps by Aquatronica) into the experimental tanks (approximately $50 \mathrm{~L}$ each) containing 70 bivalves each. During the first week of exposure, animals were exposed to three $\mathrm{pH}$ values (6 experimental tanks per $\mathrm{pH}$ value): natural $\mathrm{pH}$ (named " $\mathrm{pH} \mathrm{N}^{\prime \prime}$ ), reduced $\mathrm{pHs}$ as projected under RCP8.5 scenario for the year $2100\left(-0.4 \mathrm{pH}\right.$ units, named " $\left.\mathrm{pH}-0.4^{\prime \prime}\right)$, and 2300 ( $-0.7 \mathrm{pH}$ units, named " $\mathrm{pH}-0.7$ ") [33]. During the second and the third week, they were exposed to two environmentally realistic concentrations of diclofenac $(0.05 \mathrm{and} 0.5 \mu \mathrm{g} / \mathrm{L})$ [19], for each pH value. For each concentration (C: control without contaminant; D1: diclofenac $0.05 \mu \mathrm{g} / \mathrm{L}$; D2: diclofenac $0.50 \mu \mathrm{g} / \mathrm{L}$ ) two replicate tanks (A and B) were prepared (Figure 1). The experimental concentrations of DFC were maintained constant during the experiments by distributing in continuous the stock solutions of the contaminant with peristaltic pumps $(1 \mathrm{~mL} / \mathrm{min}$, using an MCP Process Pump, mod. ISM915A, provided with an MS/CA pump head, mod. ISM724A, by ISMATEC) from two $15 \mathrm{~L}$ glass jars. Taking into account the two combined flows $(25 \mathrm{~mL} / \mathrm{min}$ for seawater and $1 \mathrm{~mL} / \mathrm{min}$ for the contaminant solution, respectively), the concentrations of DFC in the two glass jars were calculated to be 25 times higher than the concentrations needed in the respective tanks with bivalves. Of the experimental conditions tested, the control without DFC at $\mathrm{pH} \mathrm{N}$ was considered as a reference. During the experiments, animals were fed twice a day by adding $250 \mathrm{~mL}$ of microalgae $\left(3.5 \times 10^{6} \mathrm{cells} / \mathrm{mL}\right)$ (Isochrysis galbana) in each $120 \mathrm{~L}$ tank, thus keeping an algae concentration of about $2000 \mathrm{cells} / \mathrm{mL}$ in the experimental tanks with animals. Seawater carbonate chemistry parameters (i.e., $\mathrm{pH}_{\mathrm{T}}$, total alkalinity, dissolved inorganic carbon, $\mathrm{pCO}_{2}$, and calcite and aragonite saturation state) were monitored two to three times a week. The methods in detail are reported in Munari et al. [26] and results are available in Table 1 . Bivalve mortality was checked daily, and no dead mussel was found during the experiment.

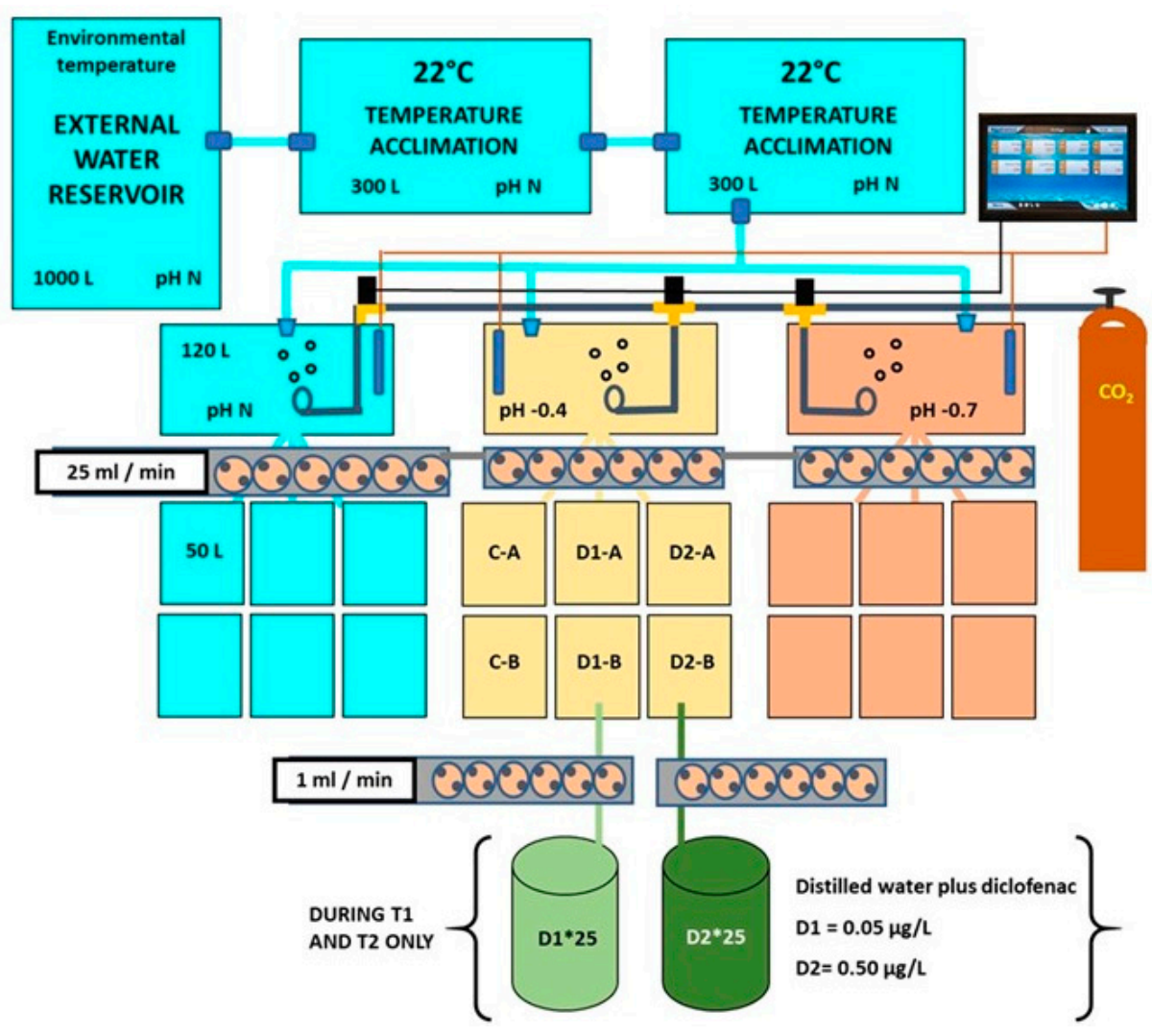

Figure 1. The experimental flow-through system. 
Table 1. Seawater carbonate chemistry parameters (mean values $\pm \mathrm{SE}$ ) throughout the experiment. $\mathrm{TA}=$ total alkalinity; $\mathrm{DIC}=$ total dissolved inorganic carbon; $\mathrm{pCO}_{2}=\mathrm{CO}_{2}$ partial pressure; $\Omega_{\mathrm{cal}}=$ calcite saturation state; $\Omega_{\mathrm{arg}}=$ aragonite saturation state.

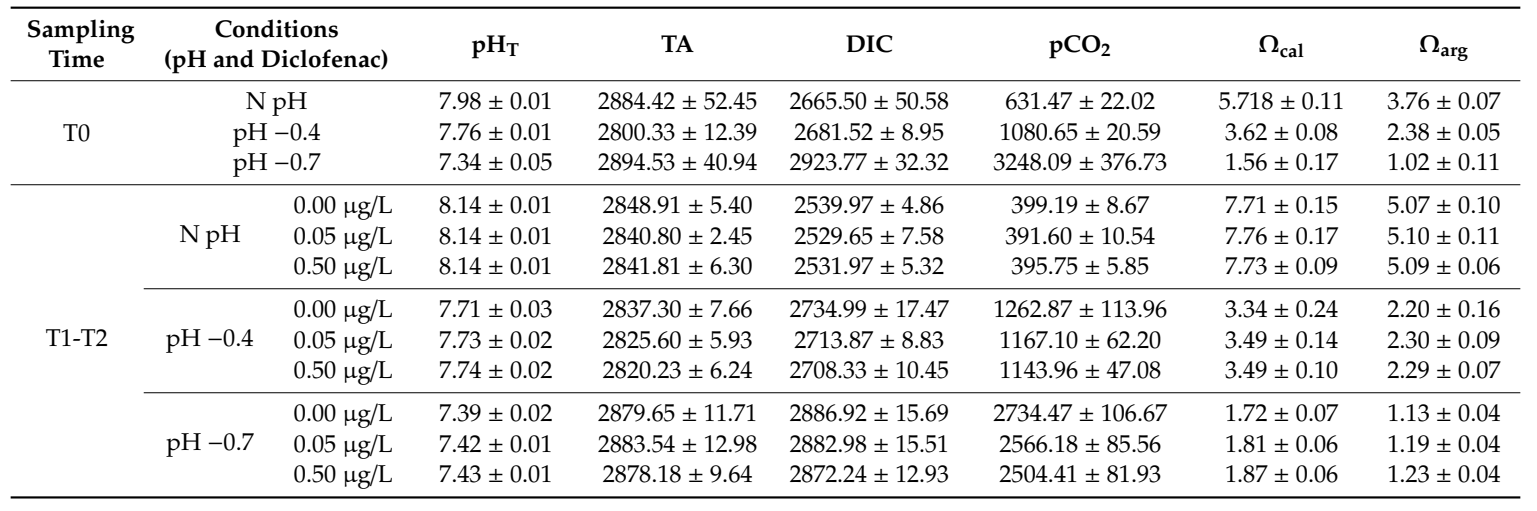

\subsection{Measurements of Physiological Parameters}

Physiological measurements (clearance rate, respiration rate, and excretion rate) were performed according to the methods described by Widdows [34]. Fifteen mussels per experimental condition were used to determine physiological rates after 7 days (T0) of exposure to three $\mathrm{pH}$ levels and after 7 and 14 days (T1 and T2, respectively) of exposure to differing $\mathrm{pH}^{*} \mathrm{DFC}$ combinations.

All measurements were carried out at the same values of temperature, salinity, and $\mathrm{pH}$ used throughout the exposure. To avoid the presence of microorganisms, seawater was previously sterilized with a UV lamp (Scudo UVC $11 \mathrm{~W}$ ) and filtered (Whatman GF/F glass microfiber filters). Filtered seawater (FSW) was then adjusted to the experimental values of $\mathrm{pH}$ by insufflating $\mathrm{CO}_{2}$. The effect due to body size was removed from physiological measurements using the following allometric Equation (1)

$$
Y=a X^{b}
$$

where " $Y$ " is the physiological measurement, " $X$ " is the dry weight of the mussel soft body tissue, " $a$ " the intercept of the regression line indicating the value of the physiological parameter/unit of dry weight $(1 \mathrm{~g})$, and " $b$ " the slope of the regression line. Coefficient " $b$ " was equal to 0.4 for the clearance rate and to 0.65 for both respiration and excretion rates, as indicated by Widdows and Johnson [35] for Mytilus edulis and successively used by Widdows et al. [36] for M. galloprovincialis. After the three physiological trials, the dry weight of each organism was measured. The soft tissues were excised from the valves and dried until constant weight in an oven at $60^{\circ} \mathrm{C}$, for at least $48 \mathrm{~h}$.

\subsubsection{Clearance Rate (CR)}

The volume of seawater cleared of suspended particles per unit of time is defined as CR. Each mussel was maintained in a static condition in a beaker containing $2 \mathrm{~L}$ of FSW and 30,000 cell/mL of I. galbana, while one beaker without a mussel acted as a blank. Throughout the assay, seawater was gently aerated to avoid the settlement of microalgae. Every 30 min over 2 h, I. galbana concentration was determined on four $5 \mathrm{~mL}$ aliquots sampled from each beaker. From each aliquot, three $60 \mu \mathrm{L}$ subsamples added with $60 \mu \mathrm{L}$ of isotonic solution (Coulter ISOTON II Diluent) were used for the measurement with a Scepter 2.0 Handheld Automated Cell Counter, Millipore ${ }^{\mathrm{TM}}$.

The CR was calculated using Equation (2)

$$
\mathrm{CR}=(\mathrm{V} / \mathrm{t}) \times(\ln \mathrm{C} 1-\ln \mathrm{C} 2),
$$

where " $\mathrm{V}$ " is the volume of seawater $(\mathrm{L})$, " $\mathrm{t}$ " is the time interval $(\mathrm{h})$, and " $\mathrm{C} 1$ " and "C2" are microalgae concentrations at the beginning and end of each time increment, respectively. For each mussel, the $\mathrm{CR}$ 
value was defined based on a $1 \mathrm{~h}$ period (two consecutive time increments), during which the decline in cell concentration was greatest [37]. Results were expressed as liters/hour.

\subsubsection{Respiration Rate (RR)}

Oxygen consumption rate or respiration rate (RR) of each mussel was determined using $700 \mathrm{~mL}$ closed plexiglass chambers (RC-400 Strathkelvin) kept at constant temperature $\left(22{ }^{\circ} \mathrm{C}\right)$. Oxygen concentration within each chamber was maintained homogeneous using a magnetic stirrer moving a magnetic stir-bar beneath a perforated plate supporting the mussel. In each chamber, the decline in oxygen partial pressure $\left(\mathrm{pO}_{2}\right)$ was determined using a calibrated membrane oxygen electrode (Strathkelvin 951302) connected to a multichannel Strathkelvin oxygen meter (Model 928). Before the assay, $30 \mathrm{~min}$ were given to the mussels to let them open their shell and to restart pumping, then oxygen consumption was measured continuously for an hour. Oxygen uptake was not considered when $\mathrm{pO}_{2}$ was below $100 \mathrm{~mm} \mathrm{Hg}$ because $M$. galloprovincialis becomes an oxyconformer at a lower level of $\mathrm{pO}_{2}$ [34]. A chamber filled with FSW only acted as a blank. $\mathrm{RR}$ was calculated with the following formula (3)

$$
\mathrm{RR}=[60(\mathrm{C} 0-\mathrm{C} 1)(\mathrm{V})] /(\mathrm{t} 0-\mathrm{t} 1)
$$

where " $\mathrm{C} 0$ " and " $\mathrm{C} 1$ " are oxygen concentrations at the beginning and end of the assay, " $\mathrm{V}$ " the volume of the chamber, and " $\mathrm{t} 0$ " and " $\mathrm{t} 1$ " the start and finish times of the assay in minutes, respectively [34]. Results were expressed as micromole $\mathrm{O}_{2}$ /hour.

\subsubsection{Excretion Rate (ER)}

ER was determined by measuring the $\left[\mathrm{N}^{-\mathrm{NH}_{4}}{ }^{+}\right]$in seawater from the $\mathrm{RR}$ chambers. At the end of the RR assay, a $50 \mathrm{~mL}$ aliquot was collected from each chamber and processed according to the spectrophotometric method described by Solorzano et al. [38].

ER was calculated using Equation (4) [34]

$$
\mathrm{ER}=(\mathrm{Ct}-\mathrm{Cb}) \times \mathrm{V} / \mathrm{t}
$$

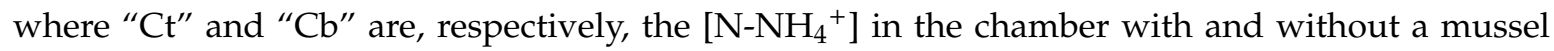
respectively, both measured at the end of the RR assay, " $\mathrm{V}$ " is the chamber volume in liters and " $\mathrm{t}$ " the incubation period in hours. Results were expressed as $\mu \mathrm{g}$-at $\mathrm{N}-\mathrm{NH}_{4}{ }^{+} /$hour.

\subsubsection{Statistical Analyses}

Data were checked for normal distribution (Shapiro-Wilk test) and homogeneity of variances (Bartlett's test). As ANOVA assumptions were not always fulfilled, a nonparametric approach was used for statistical analysis of the results. The whole data set obtained at each sampling time was statistically analyzed using a Permutational Multivariate Analysis of Variance (PERMANOVA, with 9999 permutations), considering $\mathrm{pH}$ and DFC as fixed factors. The same approach was then used to analyze the effects of $\mathrm{pH}, \mathrm{DFC}$ and their interaction on each single biomarker. PERMANOVA was also used to perform statistical pairwise comparisons. The null hypotheses tested were: at T0, no significant differences exist among $\mathrm{pH}$ levels $(\mathrm{N},-0.4$, and -0.7$)$; at $\mathrm{T} 1$ and $\mathrm{T} 2$, (i) for each $\mathrm{pH}$ tested, no significant differences exist among DFC concentrations $(0.00,0.05$, and $0.50 \mu \mathrm{g} / \mathrm{L}$ ) and (ii) for each DFC concentration tested, no significant differences exist among $\mathrm{pH}$ levels $(\mathrm{N},-0.4$, and -0.7$)$. Statistical significance was set at $p \leq 0.05$. If the number of unique values from permutations was too low, $p$-values was calculated using the Monte Carlo procedure. The software package PRIMER 6 PERMANOVA Plus (PRIMER-E Ltd., Plymouth, UK) was used for the statistical analyses. 


\section{Results}

Results of the PERMANOVA analysis are reported in Table 2. Significant effects of $\mathrm{pH}$ on the overall physiological responses of mussels were detected during the whole experiment, whereas a significant effect of DFC and its interaction with $\mathrm{pH}$ was observed only at T2. For each physiological rate, significant effects of the experimental factors (i.e., $\mathrm{pH}$ at $\mathrm{T} 0$; $\mathrm{pH}, \mathrm{DFC}$, and $\mathrm{pH} \mathrm{DFC}^{*}$ at $\mathrm{T} 1$ and $\mathrm{T} 2$ ) were also found (Table 2).

Table 2. Permutational Multivariate Analysis of Variance (PERMANOVA) results. Pseudo-F values (indicated as F) and Monte Carlo $p$-values for all physiological parameters and for each single parameter measured in Mytilus galloprovincialis throughout the experiment performed at three $\mathrm{pH}$ levels $(\mathrm{pH}$, $\mathrm{pH}-0.4$, and $\mathrm{pH}-0.7$ ), in the absence (T0: 7-days exposure) or in the presence of 0.05 and $0.50 \mu \mathrm{g} / \mathrm{L}$ diclofenac (T1: from day 7 to 14; T2: from day 14 to 21) are listed. Significant results are in bold. Abbreviation: $\mathrm{CR}=$ clearance rate, $\mathrm{RR}=$ respiration rate, $\mathrm{ER}=$ excretion rate.

\begin{tabular}{|c|c|c|c|c|c|}
\hline Sampling Time & Factors & All Variables in & CR & RR & ER \\
\hline \multirow{2}{*}{ T0 } & \multirow{2}{*}{$\mathrm{pH}$} & $\mathrm{F}_{(2,44)}=4.591$ & $F_{(2,44)}=6.266$ & $\mathrm{~F}_{(2,44)}=5.301$ & $\mathrm{~F}_{(2,44)}=8.321$ \\
\hline & & $\mathrm{p}_{(\mathrm{MC})}=\mathbf{0 . 0 1 1}$ & $\mathrm{p}_{(\mathrm{MC})}=\mathbf{0 . 0 0 5}$ & $\mathrm{p}_{(\mathrm{MC})}=\mathbf{0 . 0 0 6}$ & $\mathrm{p}_{(\mathrm{MC})}=\mathbf{0 . 0 0 4}$ \\
\hline \multirow{6}{*}{$\mathrm{T} 1$} & \multirow{2}{*}{$\mathrm{pH}$} & $\mathrm{F}_{(2,44)}=38.919$ & $\mathrm{~F}_{(2,44)}=2.832$ & $\mathrm{~F}_{(2,44)}=43.027$ & $F_{(2,44)}=5.773$ \\
\hline & & $\mathrm{p}_{(\mathrm{MC})}<\mathbf{0 . 0 0 1}$ & $\mathrm{p}_{(\mathrm{MC})}=0.073$ & $\mathrm{p}_{(\mathrm{MC})}<\mathbf{0 . 0 0 1}$ & $\mathrm{p}_{(\mathrm{MC})}=\mathbf{0 . 0 0 7}$ \\
\hline & \multirow{2}{*}{ Diclofenac } & $\mathrm{F}_{(2,44)}=2.070$ & $F_{(2,44)}=1.651$ & $F_{(2,44)}=1.780$ & $\mathrm{~F}_{(2,44)}=5.854$ \\
\hline & & $\mathrm{p}_{(\mathrm{MC})}=0.127$ & $\mathrm{p}_{(\mathrm{MC})}=0.199$ & $\mathrm{p}_{(\mathrm{MC})}=0.183$ & $\mathrm{p}_{(\mathrm{MC})}=\mathbf{0 . 0 0 7}$ \\
\hline & \multirow{2}{*}{$\mathrm{pH}^{*}$ diclofenac } & $F_{(4,44)}=2.185$ & $\mathrm{~F}_{(4,44)}=1.514$ & $\mathrm{~F}_{(4,44)}=2.248$ & $\mathrm{~F}_{(4,44)}=1.732$ \\
\hline & & $\mathrm{p}_{(\mathrm{MC})}=0.073$ & $\mathrm{p}_{(\mathrm{MC})}=0.212$ & $\mathrm{p}_{(\mathrm{MC})}=0.082$ & $\mathrm{p}_{(\mathrm{MC})}=0.162$ \\
\hline \multirow{6}{*}{$\mathrm{T} 2$} & \multirow{2}{*}{$\mathrm{pH}$} & $\mathrm{F}_{(2,44)}=13.544$ & $F_{(2,44)}=2.577$ & $\mathrm{~F}_{(2,44)}=14.453$ & $F_{(2,44)}=10.961$ \\
\hline & & $\mathrm{p}_{(\mathrm{MC})}<\mathbf{0 . 0 0 1}$ & $\mathrm{p}_{(\mathrm{MC})}=0.086$ & $\mathrm{p}_{(\mathrm{MC})}<\mathbf{0 . 0 0 1}$ & $\mathrm{p}_{(\mathrm{MC})}<0.001$ \\
\hline & \multirow{2}{*}{ Diclofenac } & $\mathrm{F}_{(2,44)}=5.903$ & $F_{(2,44)}=1.650$ & $\mathrm{~F}_{(2,44)}=6.747$ & $\mathrm{~F}_{(2,44)}=1.002$ \\
\hline & & $\mathrm{p}_{(\mathrm{MC})}=\mathbf{0 . 0 0 4}$ & $\mathrm{p}_{(\mathrm{MC})}=0.206$ & $\mathrm{p}_{(\mathrm{MC})}=\mathbf{0 . 0 0 3}$ & $\mathrm{p}_{(\mathrm{MC})}=0.996$ \\
\hline & \multirow{2}{*}{$\mathrm{pH}^{*}$ diclofenac } & $F_{(4,44)}=6.947$ & $\mathrm{~F}_{(4,44)}=3.748$ & $\mathrm{~F}_{(4,44)}=7.438$ & $F_{(4,44)}=3.939$ \\
\hline & & $\mathrm{p}_{(\mathrm{MC})}<\mathbf{0 . 0 0 1}$ & $\mathrm{p}_{(\mathrm{MC})}=\mathbf{0 . 0 1 2}$ & $\mathrm{p}_{(\mathrm{MC})}<\mathbf{0 . 0 0 1}$ & $\mathrm{p}_{(\mathrm{MC})}=\mathbf{0 . 0 1 0}$ \\
\hline
\end{tabular}

Significant differences between treatments are shown in Figure 2, at T1 and T2, only when a significant effect of the $\mathrm{pH}^{*} \mathrm{DFC}$ interaction was found. Furthermore, statistically significant differences between groups of animals exposed to different experimental $\mathrm{pHs}$ or different DFC concentrations are reported in Table 3.

Table 3. Statistical comparisons between experimental groups. Significant results are in bold.

\begin{tabular}{|c|c|c|c|c|}
\hline \multirow{5}{*}{$\mathrm{T} 1$} & & $p H N$ vs. $p H-0.4$ & $p H N$ vs. $p H-0.7$ & $p H-0.4$ vs. $p H-0.7$ \\
\hline & Respiration rate & 0.258 & $<0.001$ & $<0.001$ \\
\hline & Excretion rate & 0.008 & 0.860 & 0.002 \\
\hline & & $0.00 \mu g / L$ vs. $0.05 \mu g / L$ & $0.00 \mu g / L$ vs. $0.50 \mu g / L$ & $0.05 \mu g / L$ vs. $0.50 \mu g / L$ \\
\hline & Excretion rate & 0.630 & 0.004 & 0.018 \\
\hline \multirow{5}{*}{$\mathrm{T} 2$} & & $p H N$ vs. $p H-0.4$ & $p H N$ vs. $p H-0.7$ & $p H-0.4 v s, p H-0.7$ \\
\hline & Respiration rate & 0.049 & 0.008 & $<0.001$ \\
\hline & Excretion rate & $<0.001$ & $<0.001$ & 0.482 \\
\hline & & $0.00 \mu \mathrm{g} / \mathrm{L}$ vs. $0.05 \mu \mathrm{g} / \mathrm{L}$ & $0.00 \mu \mathrm{g} / \mathrm{L}$ vs. $0.50 \mu \mathrm{g} / \mathrm{L}$ & $0.05 \mu \mathrm{g} / \mathrm{L}$ vs. $0.50 \mu \mathrm{g} / \mathrm{L}$ \\
\hline & Respiration rate & 0.002 & 0.048 & 0.101 \\
\hline
\end{tabular}




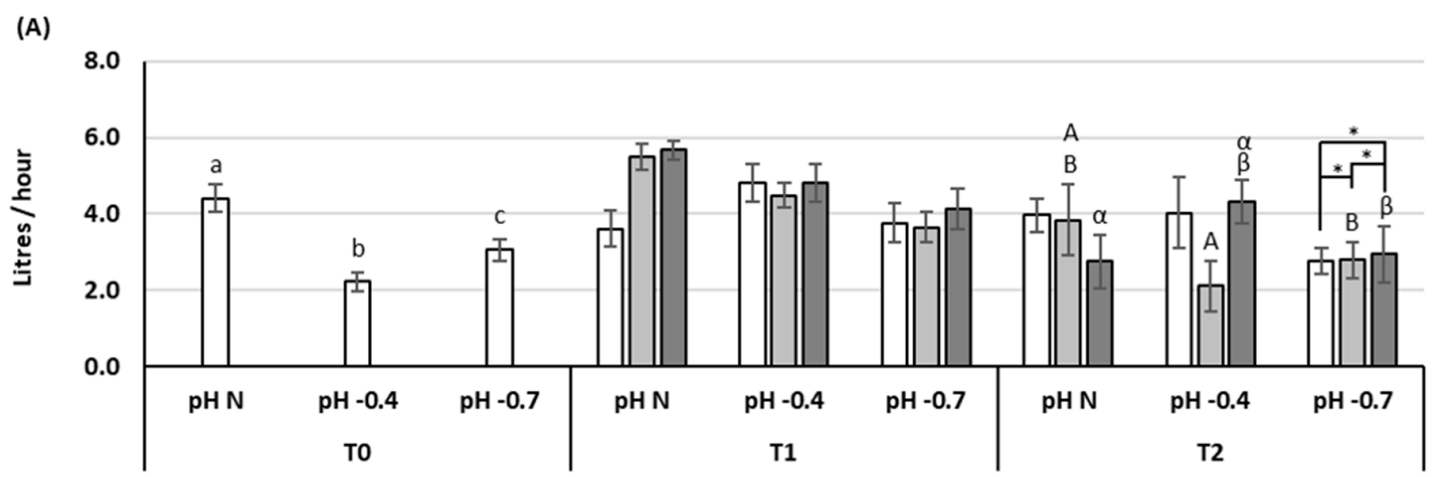

(B)

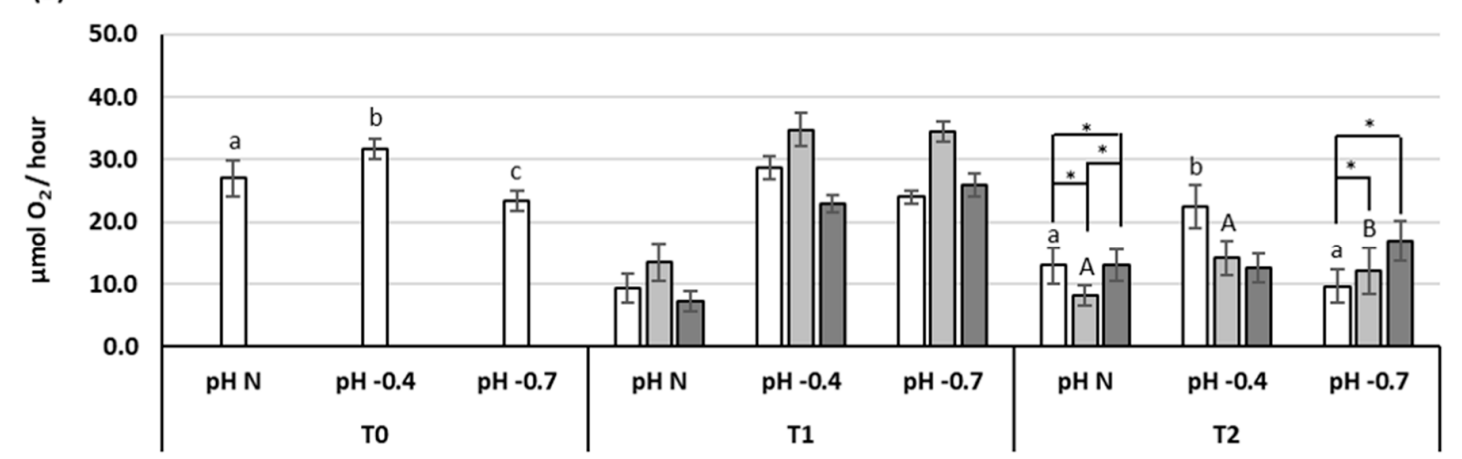

(C)

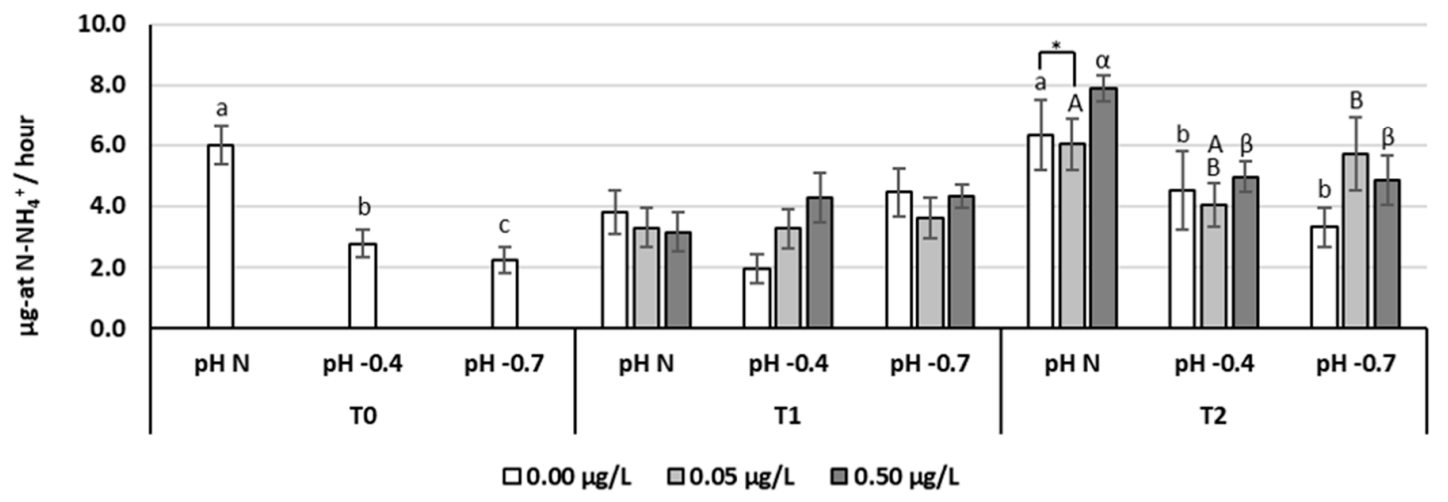

Figure 2. Clearance rate (A), respiration rate (B), and excretion rate (C) in M. galloprovincialis. Values are the means $\pm S E(n=15)$. White columns refer to a diclofenac concentration of $0.00 \mu \mathrm{g} / \mathrm{L}$, light grey to $0.05 \mu \mathrm{g} / \mathrm{L}$ diclofenac, and dark grey to $0.50 \mu \mathrm{g} / \mathrm{L}$ diclofenac. At $\mathrm{T} 0$, significant $(p<0.05)$ differences among $\mathrm{pH} \mathrm{N}, \mathrm{pH}-0.4$, and $\mathrm{pH}-0.7$ are presented with lower-case letters $(\mathrm{a}-\mathrm{c})$. At $\mathrm{T} 1$ and $\mathrm{T} 2$, significant differences $(p<0.05)$ among $\mathrm{pH} \mathrm{N}, \mathrm{pH}-0.4$, and $\mathrm{pH}-0.7$ are presented with lower-case letters $(\mathrm{a}, \mathrm{b}$, and $\mathrm{c})$ at the diclofenac concentration of $0.00 \mathrm{mg} / \mathrm{L}$, with capital letters $(\mathrm{A}, \mathrm{B}$, and $\mathrm{C})$ at the diclofenac concentration $0.05 \mathrm{mg} / \mathrm{L}$, and with Greek letters $(\alpha$ and $\beta$ ) at the diclofenac concentration of $0.50 \mathrm{mg} / \mathrm{L}$. At each $\mathrm{pH}$ value, asterisks represent significant $(p<0.05)$ variations among different diclofenac concentrations.

\subsection{Clearance Rate (CR)}

After 1 week of exposure to the three $\mathrm{pH}$ values, $\mathrm{CR}$ showed to be affected by $\mathrm{pH}$ with a significant reduction in mussels kept at $\mathrm{pH}-0.4$ and -0.7 compared to $\mathrm{pH} \mathrm{N}$ (Table 2 and Figure 2A). At T1 no significant effects of $\mathrm{pH}, \mathrm{DFC}$, or $\mathrm{pH} \mathrm{H}^{*} \mathrm{DFC}$ interaction were found. Nevertheless, at T1 CR in mussels kept at $\mathrm{pH} \mathrm{N}$ without DFC was lower than that measured in all the other conditions tested. At $\mathrm{T} 2$, a significant $\mathrm{pH}{ }^{*} \mathrm{DFC}$ interaction was found. No clear pattern of variation with increasing DFC concentration was observed at $\mathrm{pH} \mathrm{N}$ and -0.4 , whereas $\mathrm{CR}$ significantly increased with increasing DFC concentration at $\mathrm{pH}-0.7$ (Figure 2A). 


\subsection{Respiration Rate (RR)}

$\mathrm{RR}$ was significantly influenced by $\mathrm{pH}$ at $\mathrm{T} 0$, with a reduction in oxygen consumption in mussels kept at $\mathrm{pH}-0.7$ (Table 2, Figure 2B). At $\mathrm{T} 1$ as well, a significant effect of $\mathrm{pH}$ on $\mathrm{O}_{2}$ consumption was revealed by PERMANOVA. Bivalves kept at $\mathrm{pH}-0.4$ and -0.7 showed higher RR than those kept at $\mathrm{pH} \mathrm{N}$ at all DFC concentrations. At T1, no significant effects of DFC were shown, even though increased $\mathrm{O}_{2}$ consumption was recorded in individuals exposed to $0.05 \mu \mathrm{g} / \mathrm{L}$, at all pH levels. At T2, significant effects of $\mathrm{pH}$ and $\mathrm{pH}^{*} \mathrm{DFC}$ interaction were highlighted. Two opposite responses of mussels maintained at $\mathrm{pH}-0.4$ and those at $\mathrm{pH}-0.7$ were found. In particular, at $\mathrm{pH}-0.7$, there was a significant increase in $\mathrm{O}_{2}$ consumption with the increasing concentration of DFC (Figure 2B).

\subsection{Excretion Rate (ER)}

After 1 week of exposure (T0), ER significantly decreased in mussels kept at low $\mathrm{pH}$ values, with respect to controls (Table 2 and Figure 2C). At T1, significant effects of $\mathrm{pH}$ and DFC were observed with an opposite trend of response between organisms kept at $\mathrm{pH} \mathrm{N}$ and those exposed to a reduction in 0.4 units of $\mathrm{pH}$. Despite this, no significant interaction among the two factors was recorded. On the contrary, at T2, ER was significantly affected by $\mathrm{pH}^{*} \mathrm{DFC}$ interaction. A decrease in ER was measured at all DFC concentrations tested when comparing $\mathrm{pH} \mathrm{N}$ with $\mathrm{pH}-0.4$ and -0.7 . At all $\mathrm{pH}$ levels, slightly increased excretion values were observed in bivalves exposed to the highest concentration of DFC compared to their controls (Figure 2C).

\section{Discussion}

Under stressful conditions, mussels are subject to changes in their physiological performance, owing to decreased energy assumption through filtration and/or increased metabolic expenditure during respiration and excretion [39]. Reduced CR, as a measure of the bivalves' filtering activity, cannot always guarantee the proper amount of energy that is required to sustain all metabolic processes, especially those with a high energetic cost, such as growth and reproduction [40,41].

In this study, CR significantly reduced after 1 week of exposure to OA. This result is consistent with those of Liu and He [28], that reported a decrease in the clearance rate of two bivalve species, the noble scallop Chlamys nobilis, and the green-lipped mussel Perna viridis, when exposed to $\mathrm{pH} 7.7$ and 7.4, if compared to control $\mathrm{pH}$ (8.1). The effect of OA on feeding may explain the detrimental effects on physiological processes, such as growth rate, survival and calcification, observed in different species of mollusks [42-44].

However, not all species respond at the same way to stressors during experimental studies. A 3-months laboratory exposure to various $\mathrm{pCO}_{2}$ levels (290, 380, 750 and $\left.1140 \mu \mathrm{atm}\right)$ did not lead to significant alterations in CR, RR, condition index, or cellular turnover (RNA: DNA) in the king scallop, Pecten maximus, under unrestricted food supply [45]. Similarly, clearance, ingestion and respiration rates of juvenile mussels (M. galloprovincialis) were not significantly affected when animals were exposed to a reduction in seawater $\mathrm{pH}$ of about 0.3 and 0.6 for 78 days [46]. As hypothesized by the authors, the high alkalinity levels in coastal waters of Ria Formosa (SW Portugal) were probably the reason for the lack of effects. The diverging pattern of responses to OA found in literature could lead to the conclusion that there might be a different capability among species and even populations to adapt $[47,48]$.

Although the exposure to several organic and inorganic environmental contaminants is known to cause $C R$ reductions in bivalves [35], in the present study, no significant effects of DFC or $\mathrm{pH}^{*} \mathrm{DFC}$ interaction were observed, even though at $\mathrm{T} 1$, an increasing trend due to the presence of DFC was observed in animals kept at $\mathrm{pH} \mathrm{N}$ at both concentrations tested. We hypothesize that the apparent lack of effects was probably due to the environmentally relevant DFC concentrations tested. Conversely, in another study, the Baltic Sea blue mussels, Mytilus trossulus, was exposed to DFC, ibuprofen and propranolol in concentrations ranging from 1 to $10,000 \mu \mathrm{g} / \mathrm{L}$ [39]. The compounds were used both 
individually and as a mixture. Bivalves exposed to high drug concentrations showed significantly lower scope for growth, leading to the hypothesis that organisms had less energy available for normal metabolism, growth, and reproduction.

Measuring RR and ER correspond to quantify metabolic expenditure, the energy used and lost through respiration and the elimination of nitrogen compounds. Variations in abiotic factors, such as temperature, dissolved oxygen, or seawater $\mathrm{pH}$, can alter $\mathrm{RR}$ in marine organisms. Highest $\mathrm{pCO}_{2}$ values in seawater may acidify tissues and body fluids, influencing the oxygen transport [49]. In particular, M. galloprovincialis is unable to regulate the acid-base composition of the extracellular fluid under reduced $\mathrm{pH}$ conditions [50].

In this study, OA significantly reduced RR at T0. Similar findings were reported in other studies on various bivalve species, such as M. galloprovincialis [50], Crassostrea virginica [51], Crassostrea gigas [52], Ruditapes decussatus [53], and C. nobilis [28]. In bivalves, oxygen consumption often increases under exposure to environmental contaminants [34]. Interestingly, in the present study, RR values measured at $\mathrm{T} 1$ significantly increased with decreasing $\mathrm{pH}$, and at all $\mathrm{pH}$ tested, the highest value of oxygen consumption was measured at the lowest concentration of DFC. When compared to $\mathrm{T} 1$, an overall decrease in $\mathrm{RR}$ was recorded in organisms exposed to $\mathrm{pH}-0.4$ and -0.7 at $\mathrm{T} 2$, mostly in the presence of DFC.

In the energy balance, excretion represents a part of the energy loss through release of nitrogen compounds coming from protein and nucleic acid catabolism. In many bivalve species, $\mathrm{NH}_{4}{ }^{+}$is the main excreted component. Like for the other physiological rates measured in this study, nitrogen excretion can be influenced by changing environmental variables as well [54]. As an example, in three bivalve species, namely, Pinctada fucata, C. nobilis, and P. viridis, ER was significantly lower at $\mathrm{pH} 7.4$ than at $\mathrm{pH}$ 8.1 [28]. Conversely, no data are available in literature on the possible effects of DFC on ER in aquatic invertebrates, to our knowledge at least.

In this study, 1-week exposure to OA caused a significant ER reduction, with respect to controls. At T2, the same trend of variation was found in mussels kept in the absence of DFC at all pH values tested. At this time, the effects of both $\mathrm{DFC}$ and $\mathrm{pH}^{*} \mathrm{DFC}$ interaction were better revealed at $\mathrm{pH}-0.7$, with higher ER at both DFC concentrations.

M. galloprovincialis, commonly distributed and farmed in estuarine and coastal areas, are easily exposed to wide environmental changes and to many anthropogenic compounds [55].

In agreement with Michaelidis et al. [50], the decrease in ER recorded in this study at low $\mathrm{pH}$ values suggests that a reduced amino acid catabolism might represent an adaptation strategy to overcome stressful environmental variations and survive. However, this kind of plasticity seems to be affected by the presence of a contaminant, i.e., metabolic cost increases again, as confirmed by increased RR values, while the energy intake through filtration does not increase. The interaction of reduced $\mathrm{pH}$ and DFC, even at low concentrations, might lead to decreased energy availability with harmful outcomes for main life processes, such as reproduction. This could have consequently negative effects on mussel natural populations, as well as on the whole ecosystem since mussels are common keystone species on open coasts and in estuaries.

Overall, our results suggest that environmental concentrations of DFC and seawater acidification may impact the physiological performance of mussels. Further investigations, however, are needed to investigate the combined effects of global climate changes and emerging contaminants on different life stages of marine bivalves, to better understand if they can adapt to stressful conditions through generations.

Author Contributions: Conceptualization, M.M., V.M., and M.G.M.; methodology, M.M. and M.G.M.; data analysis, M.M., V.M., P.P., D.B., and M.G.M.; investigation, M.M. and V.R.; chemical analysis, P.P. and D.B.; writing-original draft preparation, M.M.; writing—review and editing, M.M., V.M., and M.G.M. All authors have read and agreed to the published version of the manuscript.

Funding: This research received no external funding. 
Acknowledgments: Special thanks are given to Andrea Sambo for his valuable technical assistance in the making of the experimental plant at the Umberto D'Ancona Hydrobiological Station.

Conflicts of Interest: The authors declare no conflict of interest.

\section{References}

1. Schiedek, D.; Sundelin, B.; Readman, J.W.; MacDonald, R.W. Interactions between climate change and contaminants. Mar. Pollut. Bull. 2009, 54, 1845-1856. [CrossRef] [PubMed]

2. Byrne, M. Global change ecotoxicology: Identification of early life history bottlenecks in marine invertebrates, variable species responses and variable experimental approaches. Mar. Environ. Res. 2012, 76, 3-15. [CrossRef] [PubMed]

3. Nikinmaa, M. Climate change and ocean acidification-interactions with aquatic toxicology. Aquat. Toxicol. 2013, 126, 365-372. [CrossRef] [PubMed]

4. Dahms, H.U. The grand challenges in marine pollution research. Front. Mar. Sci. 2014, 1, 9. [CrossRef]

5. Delorenzo, M.E. Impacts of climate change on the ecotoxicology of chemical contaminants in estuarine organisms. Curr. Zool. 2015, 61, 641-652. [CrossRef]

6. Fent, K.; Weston, A.A.; Caminada, D. Ecotoxicology of human pharmaceuticals. Aquat. Toxicol. 2006, 76, 122-159. [CrossRef]

7. Fabbri, E. Pharmaceuticals in the environment: Expected and unexpected effects on aquatic fauna. Ann. N. Y. Acad. Sci. 2015, 1340, 20-28. [CrossRef]

8. Desbiolles, F.; Malleret, L.; Tiliacos, C.; Wong-Wah-Chung, P.; Laffont-Schwob, I. Occurrence and ecotoxicological assessment of pharmaceuticals: Is there a risk for the Mediterranean aquatic environment? Sci. Total Environ. 2018, 639, 1334-1348. [CrossRef]

9. Mezzelani, M.; Gorbi, S.; Regoli, F. Pharmaceuticals in the aquatic environments: Evidence of emerged threat and future challenges for marine organisms. Mar. Environ. Res. 2018, 140, 41-60. [CrossRef]

10. Fekadu, S.; Alemayehu, E.; Dewil, R.; Van der Bruggen, B. Pharmaceuticals in freshwater aquatic environments: A comparison of the African and European challenge. Sci. Total Environ. 2019, 654, 324-337. [CrossRef]

11. Garrison, A.W.; Pope, J.D.; Allen, F.R. Analysis of Organic Compounds in Domestic Wastewater. In Identification and Analysis of Organic Pollutants in Water; Keith, C.H., Ed.; Ann Arbor Science: Ann Arbor, MI, USA, 1976; pp. 517-566.

12. Richardson, M.L.; Bowron, J.M. The fate of pharmaceutical chemicals in the aquatic environment. J. Pharm. Pharmacol. 1985, 37, 1-12. [CrossRef] [PubMed]

13. Daughton, C.G.; Ternes, T.A. Pharmaceuticals and personal care products in the environment: Agents of subtle change? Environ. Health Perspect. 1999, 107, 907-938. [CrossRef] [PubMed]

14. Kolpin, D.W.; Furlong, E.T.; Meyer, M.T.; Thurman, E.M.; Zaugg, S.D.; Barber, L.B.; Buxton, H.T. Pharmaceuticals, hormones, and other organic wastewater contaminants in U.S. streams, 1999-2000: A national reconnaissance. Environ. Sci. Technol. 2002, 36, 1202-1211. [CrossRef] [PubMed]

15. Metcalfe, C.D.; Miao, X.S.; Koenig, B.G.; Struger, J. Distribution of acidic and neutral drugs in surface waters near sewage treatment plants in the Lower Great Lakes, Canada. Environ. Toxicol. Chem. 2003, 22, 2881-2889. [CrossRef] [PubMed]

16. Bayen, S.; Zhang, H.; Desai, M.M.; Ooi, S.K.; Kelly, B.C. Occurrence and distribution of pharmaceutically active and endocrine disrupting compounds in Singapore's marine environment: Influence of hydrodynamics and physical-chemical properties. Environ. Pollut. 2013, 182, 1-8. [CrossRef]

17. Birch, G.F.; Drage, D.S.; Thompson, K.; Eaglesham, G.; Mueller, J.F. Emerging contaminants (pharmaceuticals, personal care products, a food additive and pesticides) in waters of Sydney estuary, Australia. Mar. Pollut. Bull. 2015, 97, 56-66. [CrossRef]

18. Lonappan, L.; Brar, S.K.; Das, R.K.; Verma, M.; Surampalli, R.Y. Diclofenac and its transformation products: Environmental occurrence and toxicity-A review. Environ. Int. 2016, 96, 127-138. [CrossRef]

19. Bonnefille, B.; Gomez, E.; Courant, F.; Escande, A.; Fenet, H. Diclofenac in the marine environment: A review of its occurrence and effects. Mar. Pollut. Bull. 2018, 131, 496-506. [CrossRef]

20. Vane, J.R.; Botting, R.M. Anti-inflammatory drugs and their mechanism of action. Inflamm. Res. 1998, 47, S78-S87. [CrossRef] 
21. Schwaiger, J.; Ferling, H.; Mallow, U.; Wintermayr, H.; Negele, R.D. Toxic effects of the non-steroidal anti-inflammatory drug diclofenac. Part I: Histopathological alterations and bioaccumulation in rainbow trout. Aquat. Toxicol. 2004, 68, 141-150. [CrossRef]

22. Oaks, J.L.; Gilbert, M.; Virani, M.Z.; Watson, R.T.; Meteyer, C.U.; Rideout, B.A.; Shivaprasad, H.L.; Ahmed, S.; Chaudhry, M.J.; Arshad, M.; et al. Diclofenac residues as the cause of vulture population decline in Pakistan. Nature 2004, 427, 630-633. [CrossRef] [PubMed]

23. Gonzalez-Rey, M.; Bebianno, M.J. Effects of non-steroidal anti-inflammatory drug (NSAID) diclofenac exposure in mussel Mytilus galloprovincialis. Aquat. Toxicol. 2014, 148, 221-230. [CrossRef] [PubMed]

24. Fontes, M.K.; Gusso-Choueri, P.K.; Maranho, L.A.; de Souza Abessa, D.M.; Mazur, W.A.; de Campos, B.G.; Guimaraes, L.L.; de Toledo, M.S.; Lebre, D.; Marques, J.R.; et al. A tiered approach to assess effects of diclofenac on the brown mussel Perna perna: A contribution to characterize the hazard. Water Res. 2018, 132, 361-370. [CrossRef] [PubMed]

25. Mezzelani, M.; Gorbi, S.; Fattorini, D.; d’Errico, G.; Consolandi, G.; Milan, M.; Bargelloni, L.; Regoli, F. Long-term exposure of Mytilus galloprovincialis to diclofenac, ibuprofen and ketoprofen: Insights into bioavailability, biomarkers and transcriptomic changes. Chemosphere 2018, 198, 238-248. [CrossRef]

26. Munari, M.; Matozzo, V.; Gagné, F.; Chemello, G.; Riedl, V.; Finos, L.; Pastore, P.; Badocco, D.; Marin, M.G. Does exposure to reduced $\mathrm{pH}$ and diclofenac induce oxidative stress in marine bivalves? A comparative study with the mussel Mytilus galloprovincialis and the clam Ruditapes philippinarum. Environ. Pollut. 2018, 240, 925-937. [CrossRef]

27. Munari, M.; Matozzo, V.; Chemello, G.; Riedl, V.; Pastore, P.; Badocco, D.; Marin, M.G. Seawater acidification and emerging contaminants: A dangerous marriage for haemocytes of marine bivalves. Environ. Res. 2019, 175, 11-21. [CrossRef]

28. Liu, W.; He, M. Effects of Ocean Acidification on the metabolic rates of three species of bivalve from Southern Coast of China. Chin. J. Oceanol. Limnol. 2012, 30-32, 206-211. [CrossRef]

29. Navarro, J.M.; Torres, R.; Acuna, K.; Duarte, C.; Manriquez, P.H.; Lardies, M.; Lagos, N.A.; Vargas, C.; Aguilera, V. Impact of medium-term exposure to elevated $\mathrm{pCO}_{2}$ levels on the physiological energetics of the mussel Mytilus chilensis. Chemosphere 2013, 90-93, 1242-1248. [CrossRef]

30. Matoo, O.B.; Ivanina, A.V.; Ullstad, C.; Beniash, E.; Sokolova, I.M. Interactive effects of elevated temperature and $\mathrm{CO}_{2}$ levels on metabolism and oxidative stress in two common marine bivalves (Crassostrea virginica and Mercenaria mercenaria). Comp. Biochem. Phys. A 2013, 164, 545-553. [CrossRef]

31. Freitas, R.; Almeida, A.; Calisto, V.; Velez, C.; Moreira, A.; Schneider, R.J.; Esteves, V.I.; Wrona, F.J.; Figueira, E.; Soares, A.M.V.M. The impacts of pharmaceutical drugs under ocean acidification: Newdata on single and combined long-term effects of carbamazepine on Scrobicularia plana. Sci. Total Environ. 2016, 541, 977-985. [CrossRef]

32. Almeida, A.; Freitas, R.; Calisto, V.; Esteves, V.I.; Schneider, R.J.; Soares, A.M.V.M.; Figueira, E.; Campos, B.; Barata, C. Effects of carbamazepine and cetirizine under an ocean acidification scenario on the biochemical and transcriptome responses of the clam Ruditapes philippinarum. Environ. Pollut. 2018, 235, 857-868. [CrossRef] [PubMed]

33. Hartin, C.A.; Bond-Lamberti, B.; Patel, P.; Mundra, A. Ocean acidification over the next three centuries using a simple global climate carbon-cycle model: Projections and sensitivities. Biogeosciences 2016, 13, 4329-4342. [CrossRef]

34. Widdows, J. Physiological Measurements in: The Effects of Stress and Pollution on Marine Animals; Bayne, B.L., Brown, D.A., Burns, K., Dixon, D.R., Ivanovici, A., Livingstone, D.R., Lowe, D.M., More, M.N., Stebbing, A.R.D., Widdows, J., Eds.; Praeger Press: New York, NY, USA, 1985; pp. 3-45.

35. Widdows, J.; Johnson, D. Physiological Energetics of Mytilus edulis: Scope for Growth. Mar. Ecol. Prog. Ser. 1988, 46, 113-121. [CrossRef]

36. Widdows, J.; Nasci, C.; Fossato, V.U. Effects of pollution on the scope for growth of mussels (Mytilus galloprovincialis) from the Venice Lagoon, Italy. Mar. Environ. Res. 1997, 43, 69-79. [CrossRef]

37. Widdows, J. Marine and Estuarine Invertebrate Toxicity Test. In Handbook of Ecotoxicology; Calow, P., Ed.; Blackwell Scientific: Oxford, UK, 1993; Volume 1, pp. 146-166.

38. Solorzano, L. Determination of ammonia in natural waters by the phenolhypochlorite method. Limnol. Oceanogr. 1969, 14, 799-801. 
39. Ericson, H.; Thorsén, G.; Kumbla, L. Physiological effects of diclofenac, ibuprofen and propranolol on baltic sea blue mussels. Aquat. Toxicol. 2010, 99, 223-231. [CrossRef]

40. Beesley, A.; Lowe, D.M.; Pascoe, C.K.; Widdicombe, S. Effect of $\mathrm{CO}_{2}$ induced seawater acidification on the health of Mytilus edulis. Dim. Res. 2008, 37, 215-225.

41. Thomsen, J.; Melzner, F. Moderate seawater acidification does not elicit long-term metabolic depression in the blue mussel Mytilus edulis. Mar. Biol. 2010, 157, 2667-2676. [CrossRef]

42. Kurihara, H.; Kato, S.; Ishimatsu, A. Effects of increased seawater $\mathrm{pCO}_{2}$ on the early development of the oyster Crassostrea gigas. Aquat. Biol. 2007, 1,91-98. [CrossRef]

43. Dupont, S.; Thorndyke, M. Ocean Acidification and its Impact on the Early Life-History Stages of Marine Animals. In Impacts of Acidification on Biological, Chemical and Physical Systems in the Mediterranean and Black Seas; Briand, F., Ed.; CIESM Workshop Monographs; CIESM Publisher: Monaco, 2008; Volume 36, 124p.

44. Dupont, S.; Thorndyke, M. Impact of $\mathrm{CO}_{2}$-driven ocean acidification on invertebrate early life-history-What we know, what we need to know and what we can do. Biogeosci. Discuss. 2009, 6, 109-131. [CrossRef]

45. Sanders, M.B.; Bean, T.P.; Hutchinson, T.H.; Le Quesne, W.J.F. Juvenile king scallop, Pecten maximus, is potentially tolerant to low levels of ocean acidification when food is unrestricted. PLoS ONE 2013, 8, e74118. [CrossRef] [PubMed]

46. Fernandez-Reiriz, M.J.; Range, P.; Alvarez-Salgado, X.A.; Espinosa, J.; Labarta, U. Tolerance of juvenile Mytilus galloprovincialis to experimental seawater acidification. Mar. Ecol. Prog. Ser. 2012, 454, 65-74. [CrossRef]

47. Guinotte, J.M.; Fabry, V.J. Ocean acidification and its potential effects on marine ecosystems. Ann. N. Y. Acad. Sci. 2008, 1134, 320-342. [CrossRef] [PubMed]

48. Wood, H.L.; Spicer, J.I.; Widdicombe, S. Ocean acidification may increase calcification rates, but at a cost. Proc. R. Soc. B. 2008, 275, 1767-1773. [CrossRef] [PubMed]

49. Raven, J.; Caldeira, K.; Elderfield, H.; Hoegh-Guldberg, O.; Liss, P.; Riebesell, U.; Shepherd, J.; Turley, C.; Watson, A. Ocean Acidification Due to Increasing Atmospheric Carbon Dioxide. In The Royal Society Policy Document 12; The Cloyvedon Press: Cardiff, UK, 2005.

50. Michaelidis, B.; Ouzounis, C.; Paleras, A.; Portner, H.O. Effects of long-term moderate hypercapnia on acid-base balance and growth rate in marine mussels Mytilus galloprovincialis. Mar. Ecol. Prog. Ser. 2005, 293, 109-118. [CrossRef]

51. Willson, L.L.; Burnett, L.E. Whole animal and gill tissue oxygen uptake in the Eastern oyster, Crassostrea virginica: Effects of hypoxia, hypercapnia, air exposure, and infection with the protozoan parasite Perkinsus marinus. J. Exp. Mar. Biol. Ecol. 2000, 246, 223-240. [CrossRef]

52. Lannig, G.; Eilers, S.; Pörtner, H.O.; Sokolova, I.M.; Bock, C. Impact of ocean acidification on energy metabolism of oyster, Crassostrea gigas-Changes in metabolic pathways and thermal response. Mar. Drugs 2010, 8, 2318-2339. [CrossRef]

53. Fernández-Reiriz, M.J.; Range, P.; Alvarez-Salgado, X.A.; Labarta, U. Physiological energetics of juvenile clams Ruditapes decussatus in a high $\mathrm{CO}_{2}$ coastal ocean. Mar. Ecol. Prog. Ser. 2011, 433, 97-105.

54. Han, N.K.; Lee, S.W.; Wang, S.Y. The effect of temperature on the energy budget of the Manila clam, Ruditapes philippinarum. Aquacult. Int. 2008, 16, 143-152. [CrossRef]

55. Bussell, J.A.; Gidman, E.A.; Causton, D.R.; Gwynn-Jones, D.; Malham, S.K.; Jones, M.L.M.; Reynolds, B.; Seed, R. Changes in the immune response and metabolic fingerprint of the mussel Mytilus edulis (Linnaeus) in response to lowered salinity and physical stress. J. Exp. Mar. Biol. Ecol. 2008, 358, 78-85. [CrossRef]

Publisher's Note: MDPI stays neutral with regard to jurisdictional claims in published maps and institutional affiliations.

(C) 2020 by the authors. Licensee MDPI, Basel, Switzerland. This article is an open access article distributed under the terms and conditions of the Creative Commons Attribution (CC BY) license (http://creativecommons.org/licenses/by/4.0/). 